\title{
THE BRAND EVENT PROGRAM IN TOURISM DEVELOPMENT IN UKRAINE ${ }^{\odot 2020}$ MYKHAILICHENKO H. I., KRAVTSOV S. S., ZABALDINA YU. B.
}

UDC 379.8

JEL: L83; Z31; Z32; Z33

Mykhailichenko H. I., Kravtsov S. S., Zabaldina Yu. B. The Brand Event Program in Tourism Development in Ukraine

The article is aimed at formulating the basic factors for the development of tourism event programs in the city of Kiev; formation of the tourist product and its branding in order to attract tourists. The article analyzes: event-tourism resources, event-related topics, rating of popularity of major actions of the eventive nature in the capital city, demand structure in the foreign tourism market for the purpose of travel; ranking the sources for obtaining information about tourist attractions of Ukraine by foreign tourists; components of successful event implementation and identified popular event activities are defined. In the course of analysis were used data from a survey of foreign tourists commissioned by the GIZ and the Kyiv State Administration's Office of Promotions and Tourism and from an analytical review of the results of the assessment of the quality of tourism services of the capital city. The results of the article are: definition of the term of "event program» and classification of types of tourism for the purpose of event travels; the results of studies of the demand for tourism services of the city of Kyiv among foreign tourists are analyzed; the quality and popularity of the events of the capital city are evaluated. Given the popularity of individual cultural and political events, mega-events, sporting and arts events, music and literature festivals, we offer a number of events that have already formed their own brands and are held in the well-known places of attraction; marketing measures for successful holding and location of various types of events in Ukraine. Promising places for events are the brand destinations that are already known and are gaining popularity with foreign tourists.

Keywords: event tourism, event tourism programs, holmark event, tourist attractions, tourist destinations, events.

DOl: https://doi.org/10.32983/2222-4459-2020-2-168-178

Fig.: 6. Table: 1. Bibl.: 14.

Mykhailichenko Hanna I. - D. Sc. (Economics), Associate Professor, Professor of the Department of Tourism and Recreation, Kyiv National University of Trade and Economics (19 Kioto Str., Kyiv, 02156, Ukraine)

E-mail: sv2007_71@ukr.net

ORCID: http://orcid.org/0000-0001-7066-6527

Kravtsov Sergiy S. - PhD (Public Administration), Associate Professor, Associate Professor of the Department of Tourism and Recreation, Kyiv National University of Trade and Economics (19 Kioto Str., Kyiv, 02156, Ukraine)

E-mail: s.kravtsov@knute.edu.ua

ORCID: http://orcid.org/0000-0002-2016-1974

Researcher ID: http://www.researcherid.com/N-1156-2016

Zabaldina Yuliia B. - PhD (Economics), Associate Professor, Associate Professor of the Department of Tourism and Recreation, Kyiv National University of Trade and Economics (19 Kioto Str., Kyiv, 02156, Ukraine)

E-mail: y.zabaldina@knute.edu.ua

ORCID: http://orcid.org/0000-0003-2741-5604

УДК 379.8

JEL: L83; Z31; Z32; Z33

Михайліченко Г. І., Кравцов С. С., Забалдіна Ю. Б. Бренд-івент програма в розвитку туризму в Україні

Метою статті є формування базових чинників розвитку програм івент-туризму в місті Київ; формування турпродукту та його брендування з метою залучення туристів. У статті проаналізовано: ресурси івент-туризму, тематика івент-заходів, рейтинг популярності основних заходів івентивного характеру столиці, структура попиту на ринку іноземного туризму за метою подорожі; проведено ранжування джерел отримання інформації про туристичні атракції України іноземними туристами; визначено компоненти успішного проведення івент-заходів та названо найбільш популярні з них. У ході аналізу були залучені дані опитування іноземних туристів, що проводилися на замовлення GIZ і Управління туризму та промоцій Київської міської державної адміністрації, а також аналітичного огляду результатів оцінювання якості туристичного обслуговування столиці. У результаті: визначено термін «івент-програма»; проведено класифікацію видів туризму за метою івент-подорожей; проаналізовано результати досліджень попиту на туристичні послуги міста Київ серед іноземних туристів; проведено оцінку якості та популярності івент-заходів столиці. зважаючи на популярність окремих культурних, політичних, мегаівент-заходів, івентів у сфері спорту, мистецтва, музичні та літературні фестивалі, нами запропоновано проведення низки івентів, які вже сформували свій бренд та добре відомі як місия атракиії; запропоновано маркетингові заходи щодо успішного проведення та місия локалізації різних видів івентів в Україні. Перспективними місиями для івентів є бренд-дестинації, які вже відомі та набирають популярності в іноземних туристів.

Ключові слова: івент-туризм, програми івент-туризму, холмарк-івент, туристичні атракиії, туристичні дестиначії, івент-заходи.

Рис.: 6. Табл.: 1. Бібл.: 14.

Михайліченко Ганна Іванівна - доктор економічних наук, доцент, професор кафедри туризму та рекреації, Київський національний торговельноекономічний університет (вул. Кіото, 19, Київ, 02156, Україна)

E-mail:sv2007_71@ukr.net

ORCID: http://orcid.org/0000-0001-7066-6527

Кравцов Сергій Станіславович - кандидат наук з державного управління, доцент, доцент кафедри туризму та рекреації, Київський національний торговельно-економічний університет (вул. Кіото, 19, Київ, 02156, Україна)

E-mail: s.kravtsov@knute.edu.ua

ORCID: $h$ ttp://orcid.org/0000-0002-2016-1974

Researcher ID: $h$ ttp://www.researcherid.com/N-1156-2016

забалдіна Юлія Борисівна - кандидат економічних наук, доцент, доцент кафедри туризму та рекреації, Київький національний торговельноекономічний університет (вул. Кіото, 19, Київ, 02156, Україна)

E-mail: y.zabaldina@knute.edu.ua

ORCID: http://orcid.org/0000-0003-2741-5604 
Михайличенко А. И., Кравцов С. С., Забалдина Ю. Б. Бренд-ивент программа в развитии туризма в Украине

Целью статьи является формирование базовых факторов развития программ ивент-туризма в городе Киев; формирование турпродукта и его брендирование с целью привлечения туристов. В статье проанализированы: ресурсы ивент-туризма, тематика ивент-мероприятий, рейтинг популярности основных мероприятий ивентивного характера в столице, структура спроса на рынке иностранного туризма по цели путешествия; проведено ранжирование источников получения информации о туристических аттракциях Украины иностранными туристами; определены компоненты успешного проведения ивент-мероприятий и названы наиболее популярные из них. В ходе анализа были использованы данные опросов иностранных туристов, которые проводились по заказу GIZ и Управления туризма и промоций Киевской городской государственной администрации, а также аналитического обзора результатов оценивания качества туристического обслуживания столицы. В результате: определен термин "ивент-программа»; проведена классификация видов туризма с челью ивент-путешествий; проанализированы результаты исследований спроса на туристические услуги г. Киев среди иностранных туристов; проведена оценка качества и популярности ивент-мероприятий столицы. Принимая во внимание популярность отдельных культурных, политических, мегаивент-мероприятий, ивентов в сфере спорта, искусства, музыкальные и литературные фестивали, нами предложено проведение ряда ивентов, которые уже сформировали свой бренд и хорошо известны как места аттракции; предложены маркетинговые мероприятия по успешному проведению и месту локализации разных видов ивентов в Украине. Перспективными местами для ивентов являются бренд-дестинации, которые уже известны и набирают популярность у иностранных туристов. Ключевые слова: ивент-туризм, программы ивент-туризма, холмарк-ивент, туристические аттракиии, туристические дестинации, ивентмероприятия.

Рис.: 6. Табл.: 1. Библ.: 14.

Михайличенко Анна Ивановна - доктор экономических наук, доцент, профессор кафедры туризма и рекреации, Киевский национальный торговоэкономический университет (ул. Киото, 19, Киев, 02156, Украина)

E-mail: sv2007_71@ukr.net

ORCID: http://orcid.org/0000-0001-7066-6527

Кравцов Сергей Станиславович - кандидат наук по государственному управлению, доцент, доцент кафедры туризма и рекреации, Киевский национальный торгово-экономический университет (ул. Киото, 19, Киев, 02156, Украина)

E-mail:s.kravtsov@knute.edu.ua

ORCID: http://orcid.org/0000-0002-2016-1974

Researcher ID: http://www.researcherid.com/N-1156-2016

забалдина Юлия Борисовна - кандидат экономических наук, доцент, доцент кафедры туризма и рекреации, Киевский национальный торговоэкономический университет (ул. Киото, 19, Киев, 02156, Украина)

E-mail: y.zabaldina@knute.edu.ua

ORCID: http://orcid.org/0000-0003-2741-5604

$\mathrm{N}$ owadays, events play the principal role in culture and society. Thus, they are one of the world's leading tourist products with an unlimited potential, which is primarily associated with the maturity of destination countries in innovative planning and implementation of events and manifestations through public-private partnership. Events are the activities that belong to the group of created attractions, which every destination aiming at successful tourism development should have.

Event leisure and business are public gatherings of people with certain intent. Their special appeals come partly from the limited duration and natural simplicity, which makes them different from permanent institutions and created attractions. Often, their festive atmosphere raises their importance above daily events. They may occur in every culture and community, and the interest of the contemporary society largely depends on the media coverage. Most commonly, events have a relaxing ambiance, with far less competitive and business characteristics. The role of the event is to create a specific atmosphere that characterizes the spirit of different people, their uniqueness, authenticity, tradition, hospitality, certain themes and symbolism.

There are lots of scientists who study events and their impact on the tourism industry. Mostly, they are based on research papers by D. Getz, who was one of the first who started to write on this subject. Among the authors who are interested in a scientific aspect of event tourism there are D. Getz (2008; 2013), J. Goldblatt (2004), S. Gupta (2003), V. A. Matheson (2006), I. Mihajlović (2017), J. R. B. Ritchie (2004), L. Van der Wagen (2006; 2018), J. R. Silvers (2007), and others [1-9].

The purpose of the research is to study theoretical and practical aspects in the development of the event tourism product for the city of Kyiv and to elaborate recommendations for its improvement.

The research objectives for this study are to emphasize the importance of and identify rends in the event tourism industry and ways to create a successful event tourism product.

Methods used in this study are theoretical generalization and comparison (for forming conclusions), systems approach (for analyzing indicators), and others. Evaluation of scientific publications (textbooks, study guides and scientific periodicals), analysis and synthesis of the selected information, research of the evidences collected, their comparison and optimization are also used in the course of the study.

Ukrainian travel companies are searching necessary options for a competitive product in the international market. Event tourism, which has been developing rapidly in the recent years, became Ukraine's national 
product. A new national product brand "Ukraine NOW ua", adopted by the Cabinet of Ministers of Ukraine, provides the recognition of the country by world leading tourist suppliers in foreign markets. The main slogan of Ukrainian tourism should be: "Ukraine is the Best Tourist Friendly Destination".

Nowadays, one of the most dynamically growing segments of international tourism is eventual or event tourism, which is considered by many scholars and practitioners as a real opportunity to increase tourism flows and, accordingly, to ensure sustainable socio-economic effects for a territory. Holding mass events of different subjects can create a certain level of awareness of the target audiences about the territory when the destination is in the early stages of its life cycle, accumulate additional tourist flows through diversification of offers in more developed destinations, determine the tourist specialization of the territory. Since the 1980s, events have become an inalienable part of the local tourism product and an element of marketing strategies for many destinations around the world. Such trends in the diversification of the tourism product of a destination are particularly relevant in the post-crisis period of tourism revival after significant stagnation during the quarantine measures of the pandemic coronavirus infection in 2020. The effectiveness of event programs as an element of the MICE industry can be the impetus for restoring the attractiveness of tourism destinations in the world.

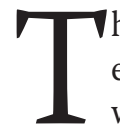
he term "event tourism" was introduced into scientific circulation in 1989 when D. Getz in his work "Event tourism: Definition, evolution, and research" proposed a methodological basis for planning event tourism [1]. Nowadays, the term is interpreted as "tourist offer", which defines all planned activities within the framework of a comprehensive approach to the development and marketing of tourist territories / destinations, and as a component of tourist demand, i. e., a special type of tourism the development of which is driven by special needs of the visitors on a particular territory [2].

Event is the basis of event tourism, the main factor of its development, actually, the reason for the trip or the supporting factor for decision making for the visitor. D. Getz elaborated on the definition of J. R. B. Ritchie, believing that the term "hallmark" describes an event of such importance in terms of traditions, attractiveness, quality, and publicity that ensures competitiveness of the destination where it is held. If events are classified according to their size and scope, it is possible to single out the following four types: mega-events (high tourist demand and high value), hallmark-events (high tourist demand and high value), regional events (periodic and one-time events) (medium tourist demand and medium value) and local, or community, events (periodic and onetime events) (low tourist demand and low value) $[1 ; 2 ; 6]$.

Another thing is local and regional events (festivals, gatherings, contests, fairs, etc.) that are focused mainly on residents. Their main purpose is not commercialization, they rather have certain cultural or social meanings. However, their level of organization or subject matter may be of some value to certain categories of tourists, stimulating tourist demand in that way. Thus, it can be argued that such activities have unequal tourism potential, only some of them become or have a potential to become part of the tourist product of a destination. The other part not only lacks such potential but are negatively characterized by tourists, which can harm the image of the events.

$\mathrm{M}$ odern scientific thought now links sustainable development of tourism not so much with the conduct of a specific event or events, but with the planning, organization, and management of a set of such events within the framework of a single concept of a local tourism product [2]. Let us dwell more on an event planning portfolio and consider possible goals of developing an IAP and approaches to making tactical decisions (Fig. 1).

The increasing competitive pressures brought on by globalization are forcing business professionals to find new ways to engage tourists. There are many definitions of event marketing. It is defined as the marketing discipline focused on face-to-face interaction via live events, trade shows and corporate meetings among other event types. Others define it as designing or developing a "live" themed activity, occasion, display, or exhibit (such as a sporting event, music festival, fair, or concert) to promote a tourism product of tourism destination.

An event is a live multimedia package with a preconceived concept, customized or modified to achieve the tourists objective of reaching out and suitably influencing the sharply defined, specially gathered target audience by providing a complete sensual experience and an avenue for two-way interaction [7].

The peculiarity of the created tourist product of the event-tourism market is the strengthening of the use of traditional cognitive tourism resources and tourist infrastructure of the main attractive destinations. Thus, 95.8 $\%$ of foreign tourists has positive impression from visiting Kyiv [10]. The most beautiful tourist attractions in Kyiv are historical and architectural monuments, museums, religious and cultural objects (Fig. 2).

Department of Tourism and Promotions of Kyiv City State Administration develop and regulate Official Tourist Information Site for visiting the city of Kyiv (http://www.visitkyiv.travel/).

All information on the city is presented on the site: monuments, exhibitions, events, maps, transport and tourism service to help tourist prepare a trip. The Internet is the most important tool to attract tourists and promote a tourism destination (Fig. 3).

Tourism marketing has changed a great deal over the last few years. Among these changes we have seen a trend towards diversification of supply, with the aim of increasing demand. To meet this challenge, online pro- 


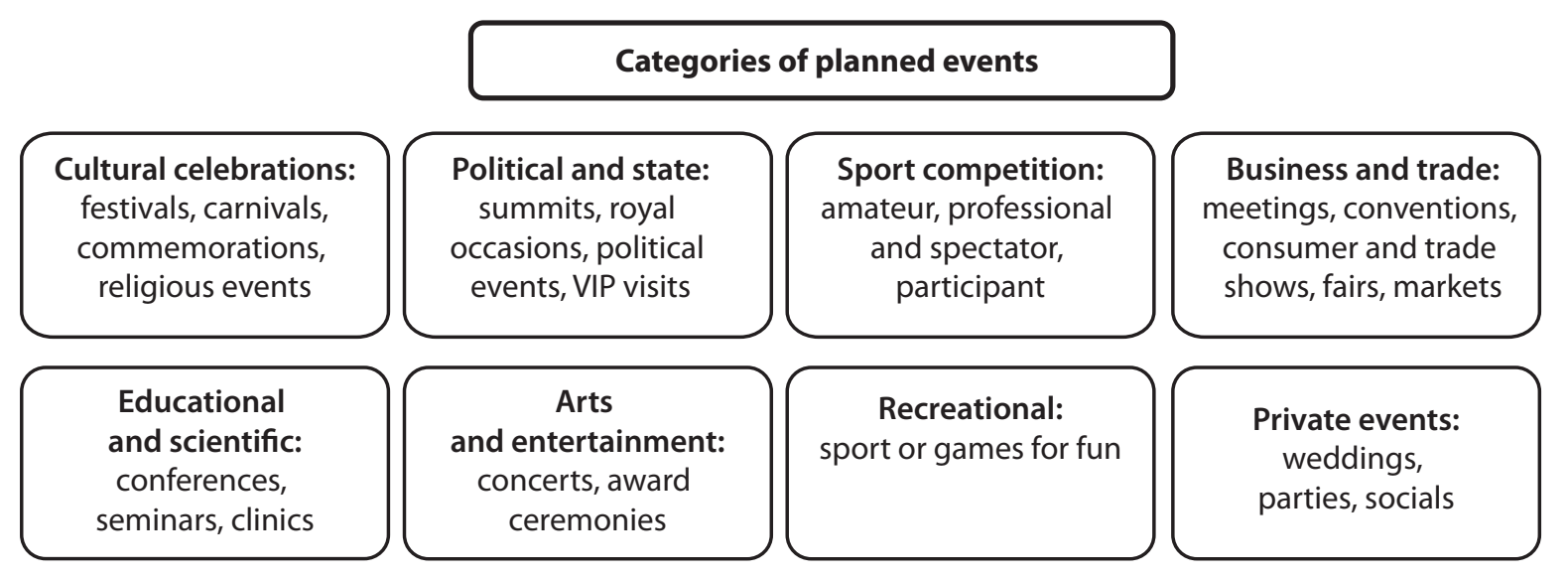

Fig. 1. Categories of planned events according to their purpose, form and program

Source: developed by the author based on [4].

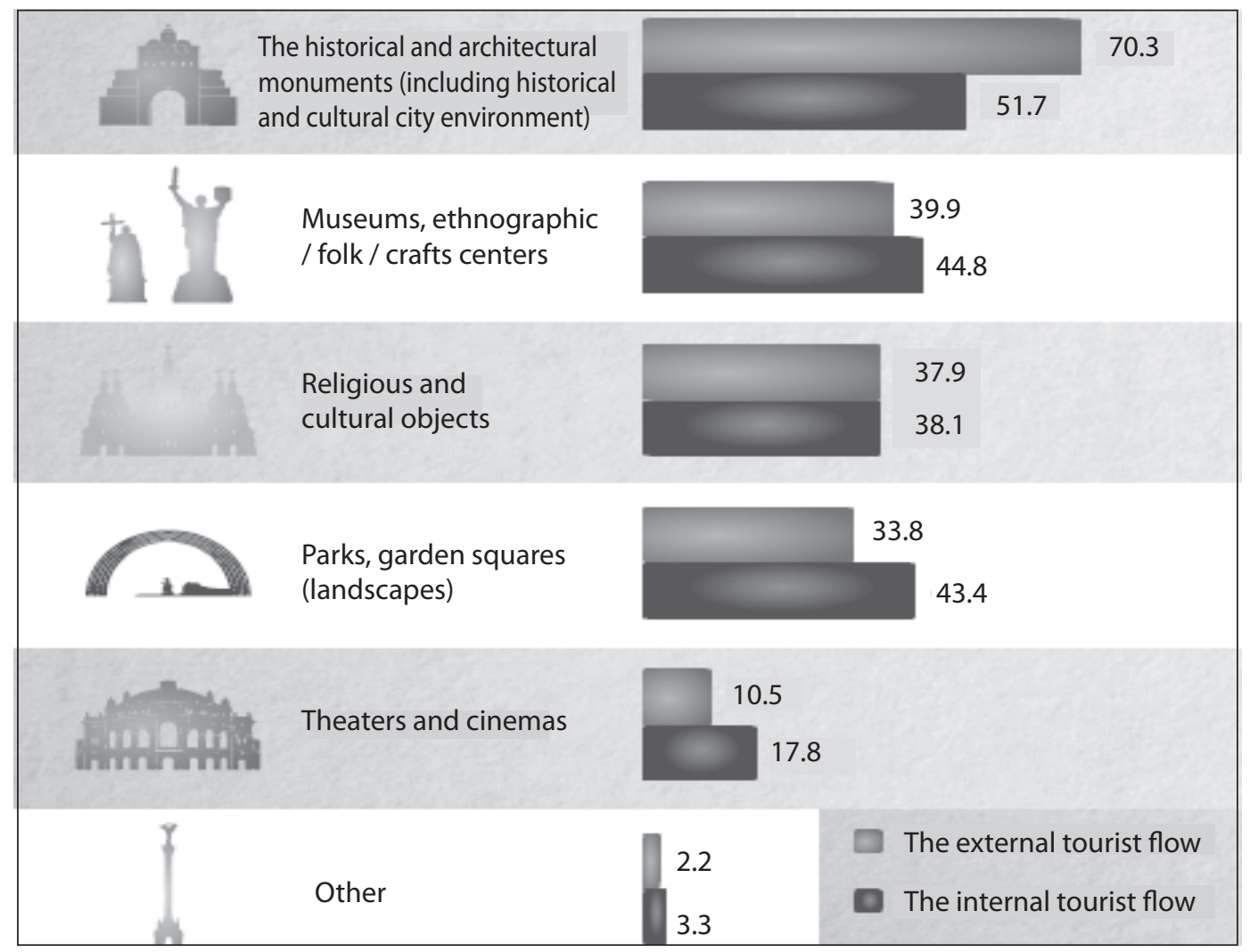

Fig. 2. Most beautiful tourist attractions in Kyiv, \% [10]

motions play an important part in publicizing tourist destinations to potential customers.

Digital marketing and, above all, social networks are important channels today in promoting tourism. But just to have a web site is not enough to secure success in the new economic market of tourism, it has to be visible. And by "visible" we mean the appearance of the site on page one of Google with the important search phrases that millions of people enter each day.

The Internet is a global network of interlinked computers operating on a standard protocol that allows data to be transferred between them. As an information exchange system, the most important aspect of the Internet is its connectivity, the ability to allow everyone to access the network. The potential of using the Internet for marketing activities is derived from its general use as an information exchange system in the digital age.

The information can be stored, indexed, retrieved, restructured and redistributed automatically by software and without human intervention. The Internet connects companies with companies, companies with customers, and people with people without regard to time, space and hardware/ software platforms.

Art, literature, gastronomy, music - the festival movement in Kyiv is gaining momentum. Various platforms (indoors and outdoors) alternately or simultane- 


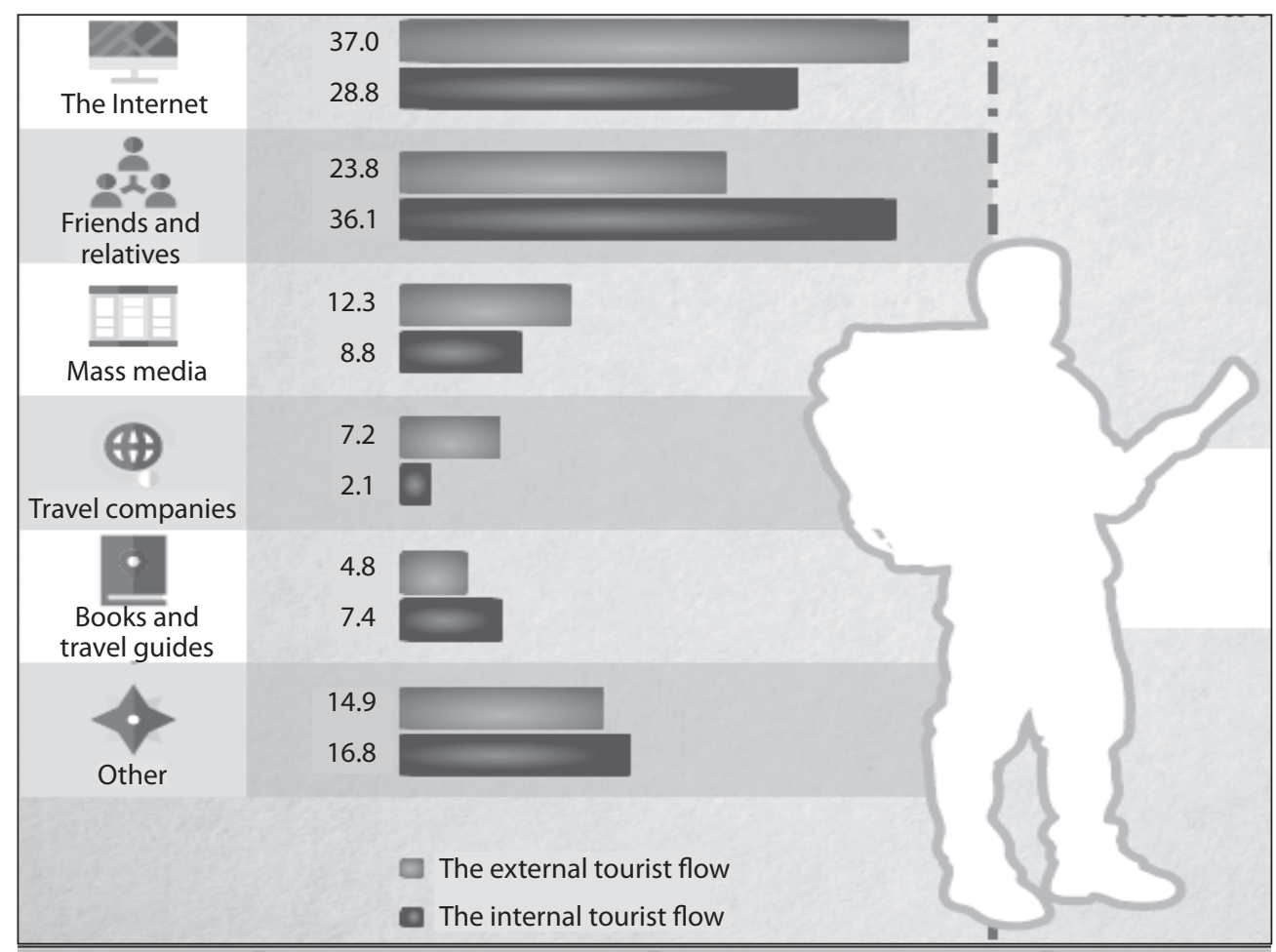

Fig. 3. Information sources about Kyiv as a tourist attraction [10]

ously gather thousands of visitors. With the number of visitors increasing, the geography of guests is also expanding: Ukraine, Europe, the USA.

$\mathrm{A}$ $\mathrm{s}$ a rule, festivals last for a few days, so the organizers pay special attention to the program. Tastes and interests of adults and children (animation, playgrounds and master classes), fans of interactive events and informative lectures, passive and active visitors are taken into account. The participants of food court are thoroughly selected, so the choice of dishes and drinks also becomes wider and more various.

TOP-5 large-scale festivals gathering thousands of visitors:

1. Atlas Weekend Music Festival was founded in 2015. Its main goal is development of festival culture in the country, attraction of foreign tourists to Ukraine and popularization of Ukrainian music in the world. Atlas Weekend 2017 gathered more than 300,000 visitors within 5 days.

2. Kraina Mriy is an international festival of ethnic music founded in 2004 with the aim of asserting Ukrainian national identity and presenting the best representatives of Ukrainian and world music. Since 2004, the festival has been attended by about 1 million people from more than 30 countries of the world.

3. GOGOLFEST is an annual multidisciplinary international festival of contemporary art. The program of the festival consists of five directions: theatre, music, cinema, literature and visual arts. Its audience is about 120000 people.
4. Ulichnaya Eda - its main goal is changing the attitude to street food, improving the culture of its preparation and consumption, and promoting domestic food producers. The audience is about 55000 visitors within two days.

5. International Book Arsenal Festival is the largest event in Eastern Europe combining literature and art. Each year, more than 200 outstanding Ukrainian and international writers, artists and experts of the book market take part in the festival. The audience for five days in 2017 was over 60000 visitors [11].

Attending events is one of the purposes of visiting Kyiv by foreign tourists. In 2017, Kyiv host a lot of international events: International Ice Hockey Federation World Championship Division I, Wizz Air Kyiv City Marathon, Eurovision-2017 Song Contest, European Diving Championships, and others (Fig. 4).

$\mathrm{T}$ he $62^{\text {nd }}$ Eurovision Song Contest 2017. It took place in the International Exhibition Centre in Kyiv, following Ukraine's victory at the 2016 contest in Stockholm with the song "1944", written and performed by Jamala.

This was the second time the contest took place in Kiev after 2005, as well as the fourth Eurovision event, after the Junior Eurovision Song Contest in 2009 and 2013. The contest consisted of two semi-finals on 9 and 11 May, and the final on 13 May 2017.

The Kyiv International Exhibition Centre is an internationally recognized venue and prides itself as the biggest expo centre in Ukraine. Spanning over an area of 58,000 square meters, the IEC comprises of three ex- 


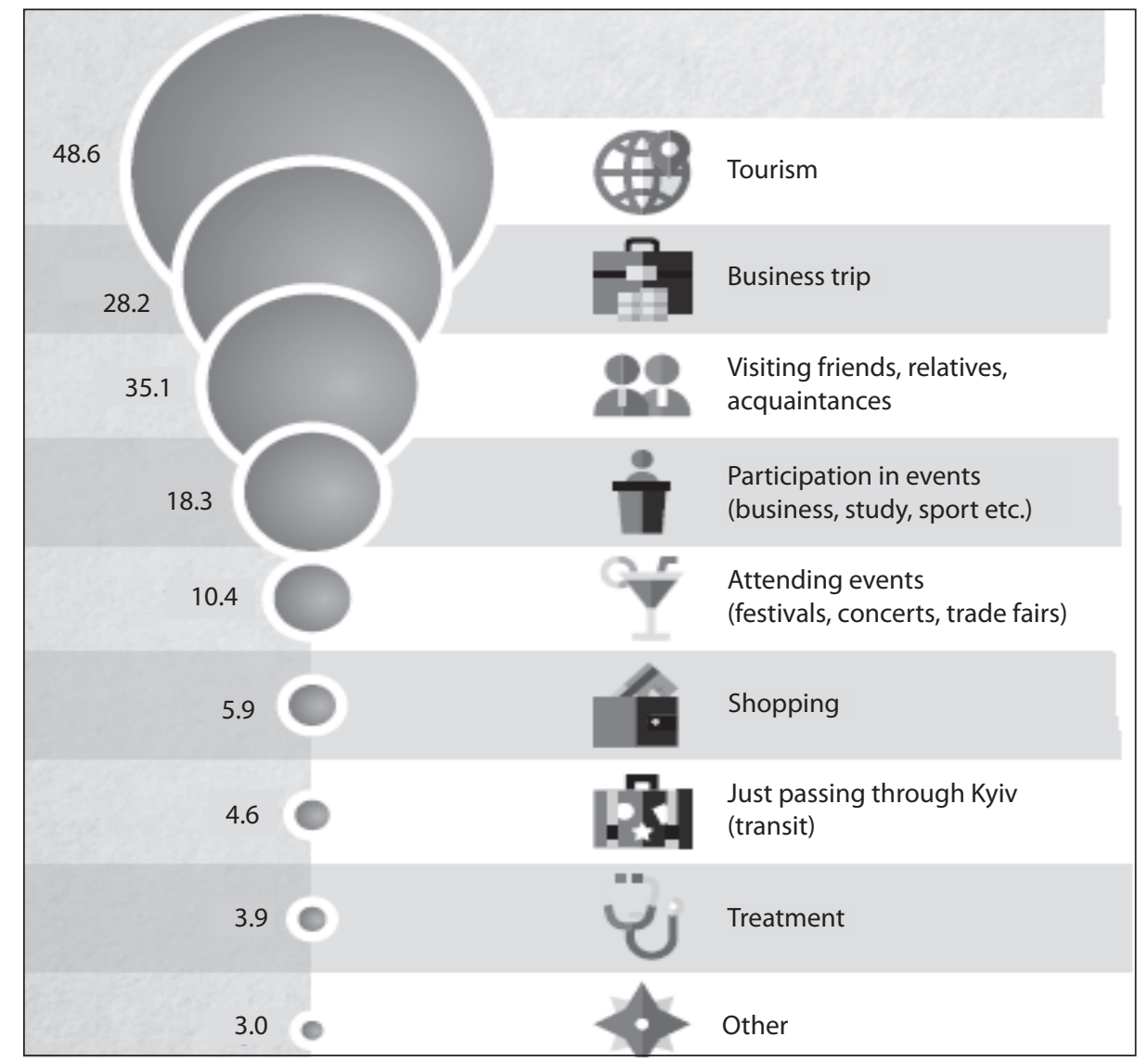

Fig. 4. Purposes of coming to Kyiv, \% [10]

ceptional first-class exhibition pavilions which includes around 28,018 square meters of exhibition space. It consists of a congress hall, 14 conference halls, restaurants, cafes, negotiation rooms, parking facilities, checkrooms, and many more. Services offered by the centre consist of internet facilities, banking services, office accommodation facilities and much more. The halls are flexible and can be used for several purposes.

$\mathrm{E}$ urovision Song Contest gives a boost to the general image and tourist attractiveness of the host country and thus helps generate income and political dividends in the future. There is evidence of a positive impact the contest can have on the way the country is perceived abroad (and even within the country itself). Suffice to say that about $180 \mathrm{mln}$ people watch Eurovision Song Contest every year. This creates an opportunity for the hosting city to "get on the (international) map".

Calculations fail to capture the positive psychological influence the event may have on the people that are tired of the war and economic hardship. Some studies argue about the existence of the so-called "psychic income" from hosting large-scale sport or cultural events. This may include the feelings of pride, excitement and all kinds of event-related positive emotions. In view of the situation in Ukraine, this kind of impact is likely to be even stronger.
Hosting the contest opens the door to other largescale international events. The host city proves its ability to organize such events, improve its infrastructure, build some contacts, and gain experience. All this may lead to receiving more income in the future.

Organizing the contest is not necessarily a burden even from a narrow short-term perspective. Expenditures in other host countries were often inflated because the contest's profitability was never a priority for them. They viewed it as a chance to improve their international image and focused on staging a spectacular show.

Ukraine's poor international image has traditionally created low expectations among visitors to the country, and this trend was very much evident among Eurovision Song Contest guests. Just over $47 \%$ of the survey respondents said Kyiv had surpassed their expectations, while a massive $92 \%$ voiced their readiness to return to Ukraine. Just 10 visitors, or less than one per cent of the surveyed, expressed disappointment at their experiences in Kyiv. When asked to identify the things that had impressed them the most, the top responses were the Ukrainian people (73\%) and Ukrainian culture (45\%). The biggest negatives were poor public transport infrastructure (26\%) and a perceived lack of English-language skills $(18 \%)$. As Ukraine seeks to engage with the international community, these results are worth dwelling on. Expensive media PR campaigns can certainly help boost 
Ukraine's international profile, but enticing people to visit Ukraine may actually be one of the most cost effective ways of improving outside perceptions of the country.

The Eurovision Song Contest was widely seen as an opportunity for Ukraine to underline the country's European credentials, and the survey results indicate that the event lived up to the expectations. International opinion polls of European Union citizens generally identity little, if any, enthusiasm for future Ukrainian EU membership, but the contest visitors felt favorably disposed toward the issue. A massive 54\% of the respondents saw Ukraine joining the EU within five years, while 19\% opted for a slightly more realistic timeframe of a decade. Just $1 \%$ said they did not see any EU future for Ukraine, making this the most Euro-optimistic survey in the Ukrainian history. While these results were undoubtedly largely due the dizzy festive atmosphere generated by the Eurovision Song Contest, they do serve as a reminder that visitors to Kyiv are generally surprised and impressed by how quintessentially European the city is. Indeed, $57 \%$ of respondents explained their belief in Ukraine's future EU membership by pointing to the country's European credentials, while 64\% said their time in Kyiv had made them more enthusiastic about Ukraine's EU membership ambitions [12].

$\mathrm{T}$ he survey also revealed the cost of continuous negative international media coverage on perceptions of Ukraine. When asked to cite the key obstacles to Ukraine's EU integration, the most popular answer was corruption (45\%). Far fewer respondents (37\%) identified the on-going war with Russia, while more than a quarter (27\%) pointed to Ukraine's oligarchs as a major barrier to closer ties with the European Union. It is highly unlikely that the Eurovision Song Contest visitors encountered any first-hand evidence of government corruption and negative oligarch influence during their short period in the country. Instead, their responses serve as a reminder of the influence exerted by endless coverage of Ukraine's corrupt elites. This is the harsh reality facing all those working to improve Ukraine's international standing. Kyiv managed to dazzle and delight visitors to its Eurovision Song Contest, but until the country's political elite stop attracting damaging headlines, Ukraine will continue to fall short in its bid to create a positive image and establish itself as an exciting new addition to the European ensemble.

There are various ways to increase the market in Kyiv tourism destination. The use of a brand name in getting the public's attention or the method of regional cooperation in tourism work well, however, the use of advertising as a primary means to achieve success requires a carefully analysis of tools in the fields of scientific, social and economic behavior. Advertising is defined as the activity or profession of producing advertisements for commercial products or services.

Features of event marketing in tourism are:

1. Wide range of events. Event marketing encompasses a wide range of event types: mega events and local events, exhibitions, trade shows, publicity stunts, themed and created events, corporate entertainment, award ceremonies. In fact, there are very few events that cannot be used for marketing purposes, as all communicate something to the target audience. Events can be used to perform a number of marketing functions: e. g., communications, relationships and loyalty building, database compilation, targeting, brand enhancement, and personal selling.

2. Goal orientation. If advertising objectives are not achieved through the event, no matter how much people enjoyed the event or how much popularity the event got, it is a complete failure at a commercial level.

3. Effective promotion and communication. It is important to get the message across to the target audience, and therefore enough research about the profile of the attendees is important to be able to communicate effectively about the tourism product.

4. Proper evaluation. Event evaluation is necessary to make the team more efficient next time it organizes an event. It helps in finding mistakes and learning from them. Event evaluation should be done immediately after the event is over or the following day. A meeting should be conducted with the team members to evaluate the event.

5. Feedback. One good way of getting feedback is through a feedback form. To get feedback from the target audience/guests, make the feedback form a part of the gift voucher. A guest can redeem the gift voucher only when he/she fills the feedback form and gives it back to an attendant. These tactics are required to get feedback, as people are generally reluctant to give any feedback in writing.

6. Location. The location chosen for an event is, perhaps, the most important aspect. The most perfect location in any exhibition areas is at the entryway to the event and near the pathway to the food stations and restrooms [4].

Fig. 5 shows the importance of event marketing for a tourism product of tourism destination:

1. It assists in brand building that is creating awareness about the launch of new tourism products/brands.

2. It highlights the added features of tourism products/services.

3. It assists in rejuvenating brands during different stages of the tourism product life cycle.

4. It assists in communicating the repositioning of tourism brands/ tourism products.

5. It assists in tourists' associating the brand personality with the target market personality.

6. It creates and maintains brand identity [5].

The main event marketing components are represented in Table 1. Planning is the most important part of running a successful event. Event planning includes all activities and issues associated with the event and how to plan them. Event plan must include the following important documents: key objectives and measures; project plan / critical path / and / or task list including all the tasks required to deliver the event; project budget; 


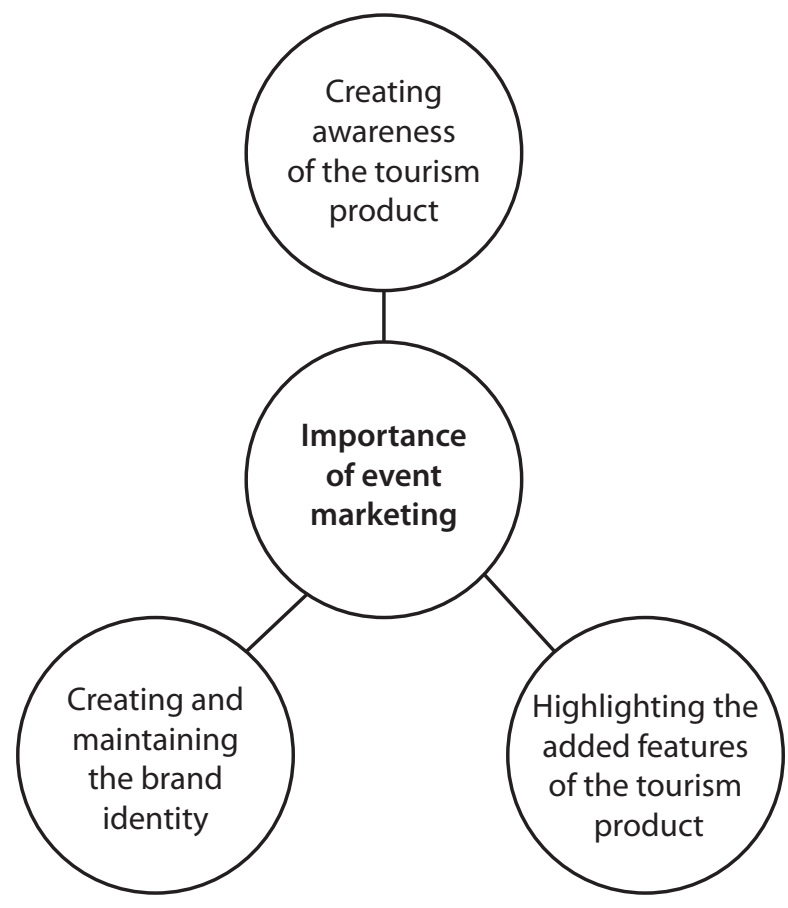

Fig. 5. Importance of event marketing in tourism

program schedule; site plan and other details about the venue; traffic management plan; security brief; contracts with suppliers and entertainers; event promotion / marketing; waste management plan; emergency management plan, including map of evacuation; risk management plan; weather / contingency plan; first aid and infrastructure and equipment list. For events that are held annually, a lot of the documentation can be utilized for future years [13].

Defining the purpose and concept of the event is an essential starting point of the event marketing process to ensure success of the event. The event committee should brainstorm some aims and objectives of the event and ensure these are specific, measurable, achievable, and realistic and have a time frame (see Tbl. 1).

$\mathrm{T}$ There is a huge variety of events that can be offered to tourists in Kyiv tourism destination, and it is hard to evaluate which of them can be most attractive. It can be sport events, concerts or big outdoor festivals, conferences and business meetings, fashion shows, fill festivals, celebrations, trade fairs, religious events or local traditional celebrations. That is the reason why it is crucial to understand which type of event can be of most interest for tourists. For this purpose, a questionnaire, where respondents were asked which types of the events they visit, was used. According to the respondents' answers, the most popular events among them were exhibitions, conferences and meetings, concerts, food festivals, and trade fairs. However, they visit all of the mentioned events (Fig. 6).

The types of events most visited by tourists in Kyiv are concerts. That is why it makes sense to develop an event product that respondents visit a lot but at the same
Components of a successful event

\begin{tabular}{|c|c|}
\hline Name & Characteristics \\
\hline Event planning & $\begin{array}{l}\text { Event purpose and concept } \\
\text { Develop an event management plan } \\
\text { Research } \\
\text { Organizing group / planning com- } \\
\text { mittee Timing }\end{array}$ \\
\hline Budget & $\begin{array}{l}\text { Income } \\
\text { Expenses } \\
\text { Sponsorship } \\
\text { Cash handling }\end{array}$ \\
\hline Venue & $\begin{array}{l}\text { Venue selection } \\
\text { Venue / site map } \\
\text { Temporary structures } \\
\text { Toilets } \\
\text { Waste management } \\
\text { Disability access }\end{array}$ \\
\hline Program & $\begin{array}{l}\text { Programs and performers } \\
\text { Program schedule / run sheet } \\
\text { Audio visual }\end{array}$ \\
\hline Marketing & $\begin{array}{l}\text { Event marketing plan (advertising, } \\
\text { online tourism and event websites, } \\
\text { banner, media) } \\
\text { Information Centre } \\
\text { Professional photography and video } \\
\text { recording }\end{array}$ \\
\hline $\begin{array}{l}\text { Event safety } \\
\text { and regulations }\end{array}$ & $\begin{array}{l}\text { Risk and opportunity management } \\
\text { plans } \\
\text { Emergency management plan } \\
\text { Traffic management } \\
\text { Security } \\
\text { Fire management }\end{array}$ \\
\hline Catering & $\begin{array}{l}\text { Food hygiene } \\
\text { Alcohol management }\end{array}$ \\
\hline Human resources & $\begin{array}{l}\text { Staffing } \\
\text { Recruiting volunteers } \\
\text { Team briefing } \\
\end{array}$ \\
\hline Post event & $\begin{array}{l}\text { Evaluation Debriefing } \\
\text { Showing appreciation }\end{array}$ \\
\hline
\end{tabular}

time keep offering concerts and keep them up to date with the current trends. Some studies of the demand for events show that Ukrainians prefer rock or pop music concerts and they most often visit cinemas. The data about tourists' preferences should be considered in developing a new event tourism product.

Before investing a lot of time and money into an event, it is important to research its essence and evaluate the likelihood of its success. It can be achieved by discovering other similar events that have been held locally or in another location.

Any available market research of these events in terms of audience participation and community acceptance should be considered. Throughout the research, it will become possible to define the viability of the event 


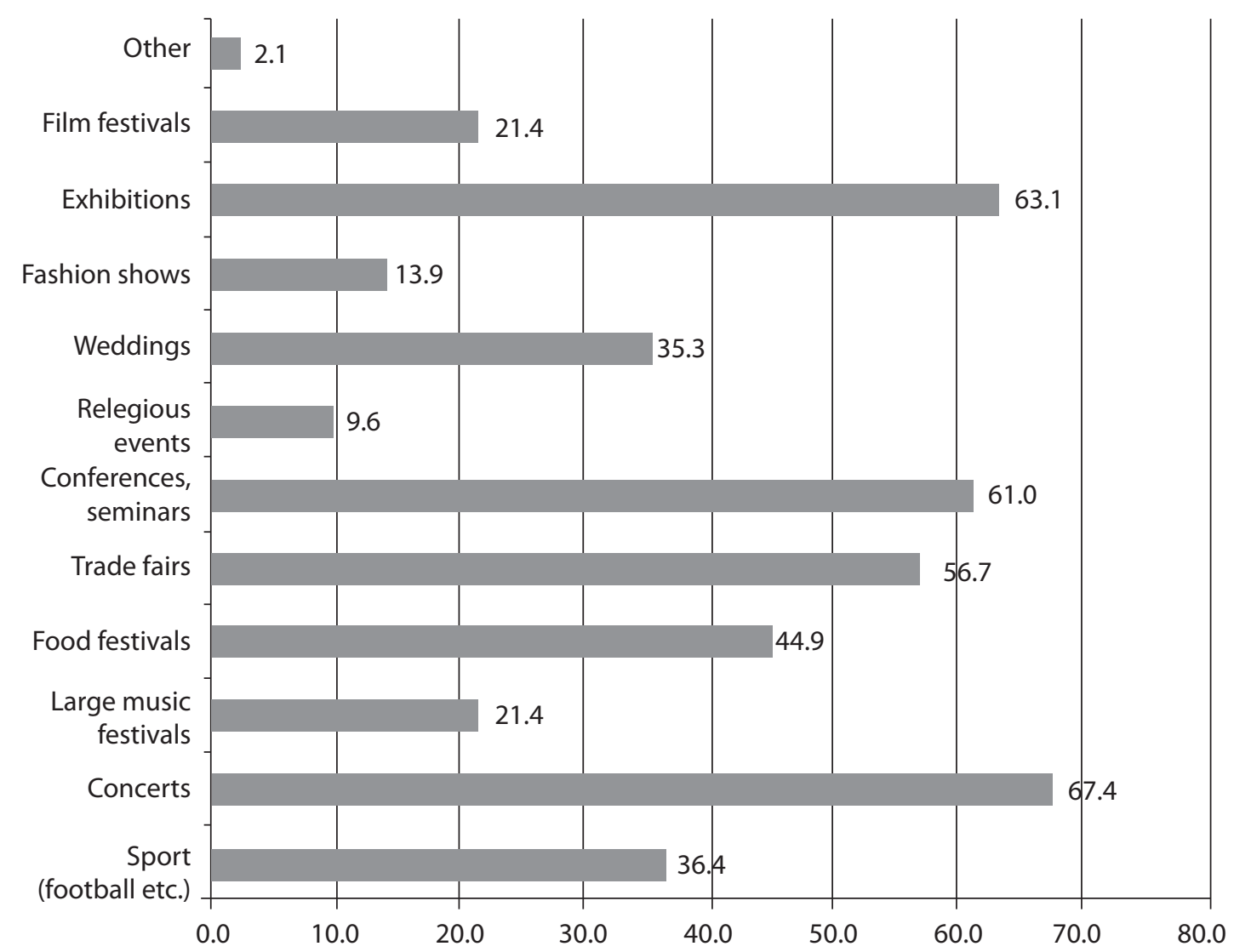

Fig. 6. Results of responding to the question "Which events do you visit in Kyiv?"

Source: developed by author based on $[17 ; 18]$.

for the audience. Then, the event can be scheduled, implemented and facilitated in the most appropriate and effective way.

I is important to establish a committee, identify roles and responsibilities of its members, or share the workload with professional staff. Depending on the nature and scope of the event, it is possible to outsource a company to help in the planning and management of the event or some components of the event. A pre-determined fee will apply. Using an external organization to manage or partly manage the event does not diminish responsibility to fulfill the obligations outlined.

Other questions should relate to the staging of the event. It can include: rate the parking ease and availability; how did you find out about this event; how do you think the company could improve the promotion; did you find the program enjoyable; please rate the catering at the event. Feedback methods need to be quick and easy for participants to access and answer. They also need to be measurable and useful for the event organizers. Suitable methods could include feedback surveys, roving evaluators talking to participants and collection of hard data such as attendance numbers.

When the event is over, it is required to organize a debriefing to review all aspects of the experience. Debriefing is a process whereby the event stakeholders have the opportunity to discuss what worked, what didn't, why it didn't work and how it could be improved. All stakeholders should be involved in this forum including events coordinators, sponsors, volunteers, security, vendors, performers and staff. It should be viewed as a worthwhile experience with recommendations greatly assisting the planning for the next event. Some points to discuss in the debrief: list of what was successful or worked well; list of what was not successful or did not work well; list of recommendations for the whole event.

It is important to acknowledge the hard work of all the stakeholders involved in the event. Regardless the extent of their contribution, it is essential to let staff and volunteers know that their efforts are appreciated. It is a good idea to plan an informal gathering for staff, to give them an opportunity to talk about the event in an informal setting, and in turn give the opportunity to facilitate a feedback forum. Don't forget to have a budget for some catering during the debrief, as a sign of appreciation. Don't forget to send out a letter or certificate of appreciation with some event photos for sponsorship.

\section{CONCLUSIONS}

Summarizing the definition of a special event, we note it as a one-time or infrequently occurring event of limited duration that provides the consumers with a leisure and social opportunity beyond everyday experience. 
Such events, which attract or have a potential to attract tourists, are often held to raise the profile, improve the image or awareness of a region.

There are many definitions of event marketing. It is defined as the marketing discipline focused on face-toface interaction via live events, trade shows and corporate meetings among other event types. Others define it as designing or developing a "live" themed activity, occasion, display, or exhibit (such as a sporting event, music festival, fair, or concert) to promote a tourism product of tourism destination.

A $\mathrm{n}$ event marketing plan is required to detail how to promote the event. The plan must describe how the public will know about the event. It should describe all the promotional opportunities that will be used for the event. The plan should include who is responsible for each promotional activity or item and the proposed date for its completion. The list of marketing activities that organizer may engage for the event includes advertising, media, banner, online tourism and event websites, direct mail.

Promotion is a key factor for the success of a special event. The main purpose that promotion serves is to attract participants, spectators or both groups to the event. Therefore, it is essential that efforts be made by many people over many months to organize a special event. Promotion is also important to the sponsor, if one exists. The objective of sponsors is to achieve as much exposure of their name, logo, and other features as possible. Sponsors, therefore, have a keen interest in pre-event promotion and in promotion that can be achieved on the day through erecting signage and product displays in view of all participants.

Kyiv is the third greenest capital in Europe. It is also considered to be one of the oldest and most beautiful cities. Tourists can find many parks and romantic tree lined boulevards, which are especially beautiful in spring and autumn. It is built mostly on hills overlooking the Dnipro River. This is a city steeped in history and bursting with culture. Golden domed churches and Soviet Statues share prominence with new modern buildings heralding an era of modern independent Ukraine. There are more than 100 museums, innumerable theatres including the Opera and Ballet Theaters, and art galleries. It is a city tourists will never tire of. Works of art and architecture of Kyiv are considered world treasures and are listed on UNESCO World Heritage site. $95.8 \%$ of foreign tourists have positive impression from visiting Kyiv. Historical and architectural monuments, museums, religious and cultural spots are among the most beautiful tourist attractions in Kyiv.

Kyiv has its own tourism brand [14]. A brand usually includes the name, term, symbol, design or a combination of all the mentioned elements which identify products and services of a certain tourism destination and differentiate them from those of competitors. Com- missioned by GIZ, a German company for international cooperation, came up with Kyiv positioning and its new visual style. "Everything starts in Kyiv" is now easily recognized due to four concise symbols. The Dnipro River, chestnut trees, capital cathedrals and sincere Kyiv heart were all brought together in a logo approved to be Kyiv's official sign, based on the City Council contest results.

Department of Tourism and Promotions of Kyiv State Administration develop and regulate activities of Tourist Information Centers. The Department develops and regulates Official Tourist Information Site for visiting the city of Kyiv (http://www.visitkyiv.travel/) [11]. It also issues Kyiv Pass to attract foreign tourists. Kyiv Smart Card for tourists is available for buying as well. The card allows the holders to visit around 40 most popular sights of the city (museums, cultural objects, art galleries and clubs) whilst saving money and time. The department also represents Kyiv in annual international tourism exhibitions, e.g., Ukraine International Travel Market (UITM) and Ukraine International Travel and Tourism Exhibition (UITT).

The festival movement in Kyiv (art, literature, gastronomy, music) is gaining momentum. Various platforms (indoors and outdoors) alternately or simultaneously gather thousands of visitors. While the number of visitors is increasing, the geography of guests is also expanding: Ukraine, Europe, the USA. TOP-5 large-scale festivals that gather thousands of visitors are Atlas Weekend Music Festival, Kraina Mriy, International Book Arsenal Festival, Ulichnaya Eda, GOGOLFEST. Foreign tourists visiting Kyiv find the attendance of the events one of the most important purposes of their trip.

$\mathrm{P}$ romotional activity can have various purposes over time, and the main communication means used are advertising, sales promotion, public relations and professional sales. The responsibility for promoting Kyiv tourism destination is vested in Department of Tourism and Promotions of Kyiv State Administration. It formulates a detailed marketing and promotional plan for the sector taking into account the quality and quantity of tourism products, the diversity of domestic, regional and international source markets, image and positioning, branding, quality and distribution of promotional materials (including e-marketing), institutional mechanisms for marketing and promotion of public-private partnership.

\section{LITERATURE}

1. Getz D. Event tourism: Definition, evolution, and research. Tourism Management. 2008. Vol. 29. Issue 3. P. 403-428.

DOI: https://doi.org/10.1016/j.tourman.2007.07.017

2. Getz D. Event Tourism Concepts, International Case Studies, and Research. Cognizant Communication Corp., 2013. 434 p.

3. Goldblatt J. Special Events: Event Leadership for a New World. $4^{\text {th }}$ ed. John Wiley \& Sons, 2004. $528 p$. 
4. Gupta S. Event Marketing: Issues and Challenges. IIMB Management Review. June 2003. P. 87-96. URL: http:// citeseerx.ist.psu.edu/viewdoc/download?doi=10.1.1.4 65.2724\&rep=rep $1 \&$ type $=$ pdf

5. Mihajlović l., Vidak M. The Importance of Local Events for Positioning of Tourist Destination. European Journal of Social Sciences. 2017. Vol. 4. Issue 4. P. 228-239. URL: http://journals.euser.org/files/articles/ejser_ may_august_17_nr_2/Iris.pdf

6. Ritchie J. R. B. Assessing the Impact of Hallmark Events: Conceptual and Research Issues. Journal of Travel Research. 2004. Vol. 23. No. 1. P. 2-11. DOI: https://doi.org/10.1177/004728758402300101

7. Van der Wagen L., White L. Event Management: For Tourism, Cultural, Business and Sporting Events. $5^{\text {th }} \mathrm{ed}$. Cengage Learning, Australia, 2018. 544 p.

8. Silvers J. R. Risk Management for Meetings and Events. Butterworth-Heinemann, Burlington, 2007. 384 p.

9. Van der Wagen L. Human Resource Management for Events; Managing the Event Workforce. ButterworthHeinemann, Burlington, 2006. 272 p.

10. Sociological research of tourist flows to Kyiv / Executor: Centre for independent sociological research "OMEGA". URL: http://omega-research.com.ua

11. Department of Tourism and Promotions. URL: http:// www.visitkyiv.travel

12. Brand Ukraine Eurovision Boost. URL: http://bunews. com.ua/society/item/eurovision-boosts-brandukraine

13. Румянцев Д., Франкель Н. Event-маркетинг. Все об организации и продвижении событий. СПб. : Питер, 2017. 320 c.

14. Mazaraki A., Boiko M., Mykhailichenko G. National Tourist Brand: Priorities And Formation Resources. Economic Annals-XXI. 2013. No. 9-10 (1). P. 42-46. URL: http:// soskin.info/userfiles/file/2013/2013/9-10(1)_2013/ Mazaraki\%20.pdf

\section{REFERENCES}

Brand Ukraine Eurovision Boost. http://bunews.com.ua/ society/item/eurovision-boosts-brand-ukraine

Department of Tourism and Promotions. http://www.visitkyiv.travel

Getz, D. "Event tourism: Definition, evolution, and research". Tourism Management, vol. 29, no. 3 (2008): 403-428. DOI: https://doi.org/10.1016/j.tourman.2007.07.017

Getz, D. Event Tourism Concepts, International Case Studies, and Research. Cognizant Communication Corp., 2013..

Goldblatt, J. Special Events: Event Leadership for a New World. John Wiley \& Sons, 2004.

Gupta, S. "Event Marketing: Issues and Challenges". IIMB Management Review. June 2003. http://citeseerx.ist. psu.edu/viewdoc/download?doi=10.1.1.465.2724\&re $\mathrm{p}=$ rep 1 \&type $=p d f$

Mazaraki, A., Boiko, M., and Mykhailichenko, G. "National Tourist Brand: Priorities and Formation Resources". Economic Annals-XXI. 2013. http://soskin.info/userfiles/file/2013/2013/9-10(1)_2013/Mazaraki\%20.pdf

Mihajlovic, I., and Vidak, M. "The Importance of Local Events for Positioning of Tourist Destination". European Journal of Social Sciences. 2017. http://journals.euser.org/ files/articles/ejser_may_august_17_nr_2/Iris.pdf
Ritchie, J. R. B. "Assessing the Impact of Hallmark Events: Conceptual and Research Issues". Journal of Travel Research, vol. 23, no. 1 (2004): 2-11.

Rumyantsev, D., and Frankel, N. Event-marketing. Vse ob organizatsii i prodvizhenii sobytiy [Event Marketing. All about Organizing and Promoting Events]. St. Petersburg: Piter, 2017.

"Sociological research of tourist flows to Kyiv". Executor: Centre for independent sociological research "OMEGA". http://omega-research.com.ua

Silvers, J. R. Risk Management for Meetings and Events. Burlington: Butterworth-Heinemann, 2007.

Van der Wagen, L. Human Resource Management for Events; Managing the Event Workforce. Burlington: Butterworth-Heinemann, 2006.

Van der Wagen, L., and White, L. Event Management: For Tourism, Cultural, Business and Sporting Events. Australia: Cengage Learning, 2018. 